\title{
The Foreign Direct Investments in the United States during the period of 1980-2015
}

\author{
PIOTR ŁASAK
}

The Jagiellonian University in Kraków, Institute of Economics, Finance and Management

\begin{abstract}
The aim of this article is to examine the Foreign Direct Investments (FDI) in the United States during the period of 1980-2015. It was analyzed the flows and stocks of these investments, their structure with the division into the main sectors of industry, the major investment partners and the branches of industry in which the United States are connected with the rest of the world through manufacturing processes.

On the basis of the size and structure of FDI flows between the United States and its' major investment partners it can be concluded that developing countries are not the major investment partners for the United States, even in "manufacturing" investment outflow, but the developed countries have a more important position in the area. In the past the main motives for FDI were: market-seeking and efficiency-seeking. The main motive which drives the investments from emerging markets to the United States during the last several years is the strategic asset-seeking. The state policy in the United States towards the FDI should be very subtle.
\end{abstract}

Paper type: review article

Keywords: Foreign Direct Investments, industrial development, USA

\section{Introduction}

Foreign Direct Investments (FDI) are one of the most desirable forms of capital flows. These investments bring a very positive effect for investors, but also play an important role in the host country development strategies. Despite many advantages of FDI, among politicians, public opinion, and some economists, comes up a recurring discussion about the consequences of this form of capital flow in the home 
country. The discussion also involves one of the world's largest economy - the United States.

The aim of the article is to analyze the United States FDI during the period of 1980-2015. This is a period in which FDI began to play an increasingly important role among international capital flows. The article shows the position of the country from the point of view of these investments. The analysis takes into account several aspects: the direction of the capital flows (inflows and outflows), the main sectors of investments, the main investment destinations and the structure of the FDI in the manufacturing sector. The theoretical basis of the analysis is the classical theory of FDI, which includes their main motives, determinants, and consequences.

Before the analysis of FDI in the United States, it is necessary to pay attention into two issues. First is the political approach to this category of investment in the country, second, the main determinants of them. Whereas the FDI outflow in the case of the United States was a rather spontaneous process, the FDI inflow was supported by a conscious policy implemented by consecutive White House administrations. In recent years appeared critical opinions about FDI outflow from the United States, which is blamed for transfer of jobs abroad, strengthening foreign competition and some other negative mechanisms. The policymakers are searching for ways to curb all these negative processes. The reverted approach is applied to the FDI inflow as well. Whereas in the past the FDI inflows were treated as an important feature strengthening the domestic economy, nowadays more important role plays the question about the source of capital and the accompanying concerns. Some actions are undertaken to protect local businesses from the inflow of foreign capital.

The second important aspect is the analysis of the determinants of this category of capital flows. In the literature are enumerated main motives of FDI flows: natural resource-seeking investment, market-seeking investment, efficiency-seeking investment and strategic asset-seeking investment (Dunning, 1980). This division is important for better understanding the investor behavior during the analyzed period and their consequences to the United States economy. Whereas the FDI outflow is determined by the market-, resources- and efficiency-seeking, the FDI inflow to the United States is treated as motivated mainly by the strategic asset-seeking motive. It implies the state approach into this category of investment.

The article does not concentrate on theoretical analysis, but on data analysis of this category of capital flows (the size, the direction, the investment position of the United States, the investment structure, etc.). There was made an attempt:

- to answer the question: Whether the relatively lax FDI flow in the United States was an unfavorable process for the country's economy, and if a better option would be to implement a more rigorous state policy in order to exert a greater influence on this category of investment?

- to assess whether the actions undertaken by the White House administrations had a significant impact on FDI flows? 
The second task is to judge how important was the imbalance between the FDI outflow and inflow in the United States.

The first part of the article describes the United States government approach toward the FDI since the 1980s up to date. The attention has been devoted to the applied government policy. The second part contains the data of FDI during the analyzed period. The third and the final part of the paper contains the discussion referring to the posted questions. In the study was applied desk research of the literature studies and the FDI statistics. The analyzed data come from UNCTAD and the U.S. Bureau of Economic Analysis (the government agency that provides official industry statistics).

\section{The approach in the United States to Foreign Direct Investments during the 1980-2015}

The United States belongs to the countries which are most liberalized for crossborder capital flows. It stems from the fact that FDI played a crucial role in ensuring economic growth and prosperity of this country. The United States investments abroad enhanced the domestic multinationals competitiveness and were driving export. On the other hand, foreign inflows compensated for a shortage of savings at home and impacted the economy in many ways, e.g.: boosting wages, strengthening of manufacturing and services processes, rising productivity, etc. Despite many advantages of this kind of capital flow, nowadays they cause a lot of controversies, because the policymakers and the public usually tend to focus on potential negative aspects of FDI outflow, due to concerns that they lead to displacements of the domestic employment, capital investment and tax revenues. This point of view is not supported by the science because contemporary research shows, that foreign investments are not substitutes to domestic ones, and the process of investment abroad, triggered by foreign economic growth has a positive impact on home economies (Tang \& Altshuler, 2015; Desai, Foley, \& Hines, 2009).

The investment outflow from the United States is very closely related to the changes in the world economy and the process of economic globalization. The United States became the world's leading source of FDI after the Second World War. The location was dependent on the United States industry needs, e.g. originally the need for access to raw materials and new markets. The important role played as well the host country's government policies (e.g. Investment subsidies or local content requirements). The United States domination in the world outward FDI continued until the end of the 1970s. Due to some processes in the global economy (increase of international competition, crises and economic recessions in emerging markets, the variability of the US dollar exchange rate) and the situation of the United States 
economy, the country in the 1980s lost its leading position as the largest FDI source. Instead, it became the largest recipient of FDI (Campbell \& McElrath, 1990).

During the presidency of Ronald Reagan (1981-1989), the United States have formally initiated foreign investment policy (sometimes called as: Open Investment Policy). In 1983 President Reagan announced that the United States welcome inflow of FDI and that the foreign investors should be able to make the same kinds of investment, under the same conditions, as a nationals of the host country (Statement on International Investment Policy, 1983). The same approach was continued consequently by the consecutive presidents: George H. Bush, William Clinton, George W. Bush and Barack Obama.

The liberal approach toward FDI which took place since the President's Reagan initiative, in not free of concerns about the side effects of the investments. Consequently, in parallel with the very liberal approach, were implemented some regulations aimed at protecting the domestic market against the negative impact of these investments. This covers few key state activities aimed at ensuring the safety of these investments. Among them are: the creation of the Committee on Foreign Investment in the United States (CFIUS) (1975), the Exon-Florio Amendment (1988) and the Foreign Investment and National Security Act of 2007 (FINSA).

The first regulation was introduced in 1975 when was established the CFIUS. The main role of the agency is to coordinate the policy on foreign investment, to provide security for the domestic firms and to protect them from foreign acquisition.

The second most important activity imposed during the last four decades was the Exon-Florio Act of 1988. It gave the United States' president the power to block a foreign acquisition, which is treated as adverse for domestic companies. President Reagan allowed the CFIUS the competence to review and analyze data on foreign investment and to advise him on the FDI transactions.

During the presidency of George W. Bush policymakers in the United States focused on the economic benefits of foreign investment and strengthened the support for the open economy. They were convinced that free and open international investment regime is crucial for the economic growth (Alvarez, Sauvant, Ahmed, \& Vizcaíno, 2011). Consequently the White House administration made many efforts to attract foreign investors. Among the tools aimed at reaching this goal were programs: Invest in America and Open Investment Initiatives. Except for such programs the country undertook some additional activities, e.g. signed bilateral investment treaties with other countries. Despite the liberal approach, the president George W. Bush administration was concerned about the oversight of the foreign investments in the United States. At the end of the presidency was introduced next important legislation for FDI - the Foreign Investment and National Security Act of 2007 (FINSA). It established more stringent rules for the state review and formal investigation of foreign transactions in the United States. The legislation provided the United States Congress a greater power to oversight CFIUS and to act on behalf of the national security. Another initiative aimed at protecting domestic economy and 
oriented on the behavior of the domestic multinational companies was the American Jobs Creation Act of 2004 which caused a sharp drop of the United States' FDI abroad since 2005 (the companies were motivated by one-time tax provisions due to investments in their home country). The significant impact on the FDI flows in the United States was the financial crisis of 2007-2009 as well, which sharply reduced the availability of investment funds (Jackson, 2013).

\section{Foreign Direct Investment trends}

The United States historically has been the most attractive source and destination of FDI but since the late 1980s, the leadership position of this country has eroded. Despite the decline of the United States' share of global FDI flows, the country remained an attractive location for foreign investment. It is the largest economy and the most important market. The nominal value of the FDI inward stock in the United States is growing during the analyzed period, however, the FDI flows were very volatile during the second part of the period (especially years 1995-2015) (Figure 1 and Figure 2).

Looking at the Figures 1 and 2 it can be concluded that the investment position (FDI inflow and outflow from the United States) in the analyzed period was substantially balanced and only during the last decade the outflows exceeded inflows. Before the William Clinton presidency, the flows were relatively smooth and since this presidency occurred at higher growth of the nominal value of the investments. It is characteristic that during the Clinton presidency, there was a large inflow of the FDI to the United States. Later, during the crises of 2001 and 2007, the inflow declined and noticeably increased outflow. The flows of FDI led to the changes in the FDI stocks. Both FDI inward stock and outward stock were at the similar level up to the crisis in 2001. Since the crisis the FDI outward stock increased and this situation has persisted through the whole remaining period. The rebound of FDI inflow to the United States took place during the Barack Obama presidency.

The very important issue regarding the United States FDIs is the structure of these investments. It is very often highlighted by the critics that the main purpose of the investments was to transfer production processes outside the United States. The Figure 3 shows that the share of the United States FDI abroad in "manufacturing" sectors initially increased but later, since the beginning of the 1990s it decreased and in 2015 the "manufacturing" stated only 15\% of the whole FDI outflow from the United States. The dominant position of manufacturing investments was replaced by the "nonbank holding companies."' The investments in other sectors

1 The Bureau of Economic Analysis defines the nonbank holding companies as an engagement in holding the securities or financial assets of companies and enterprises for the purpose of owning a controlling interest in them or influencing their management decisions. A business in this industry is not concentrated on day-to-day management operations of the firms whose securities they hold. 


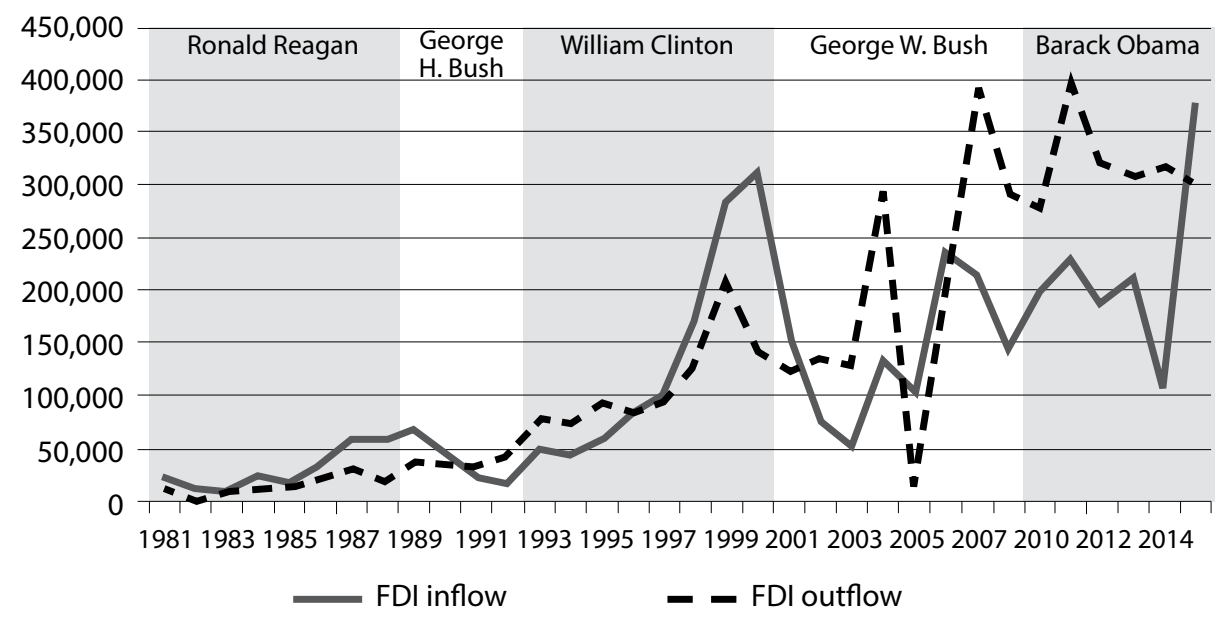

Figure 1. Foreign Direct Investment in the United States inflow and outflow during the period of 1980-2015 (millions of US dollars).

Source: based on UNCTAD Statistics (n.d.).

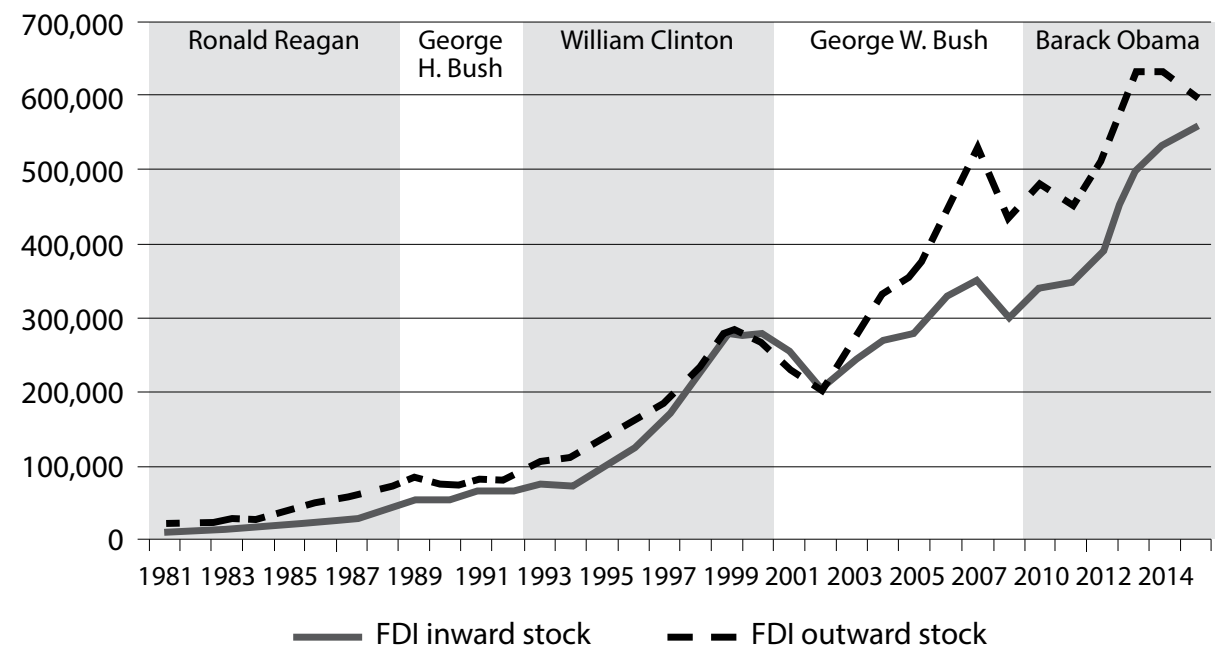

Figure 2. Foreign Direct Investment in the United States inward stock and outward stock during the period of 1980-2015 (millions of US dollars).

Source: based on UNCTAD Statistics (n.d.). 
play a less important role in the structure of the FDI outflow. They were diversified between different sectors of the industry.

The situation is quite different in the case of inflow of FDI to the United States (Figure 4). It can be noticed that over the analyzed period there still remained a very large share of investments in the "manufacturing" sector. In the year 2015 they had a $47 \%$ stake, what was the same level as in 1980 and 1990 . The relatively large share had also "trade" (both retail and wholesale) and "financial services." In all these sectors the United States became an important market for foreign investors.

1982

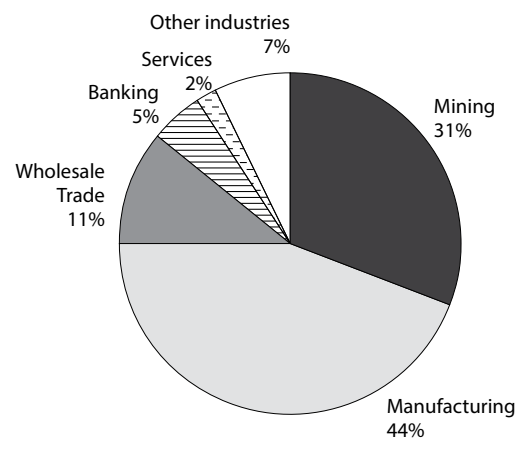

2005

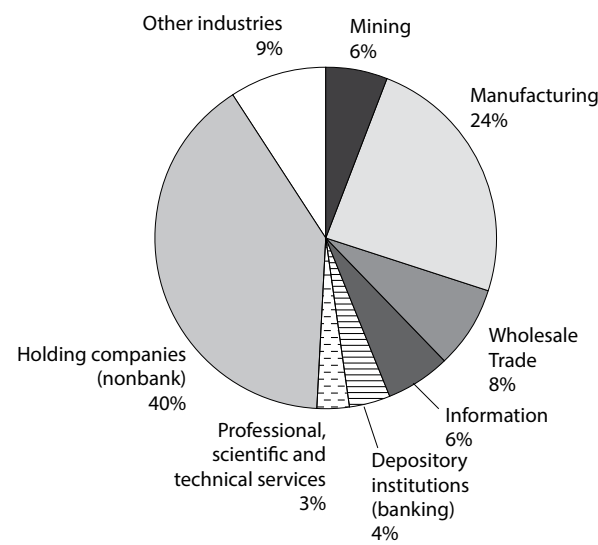

1990

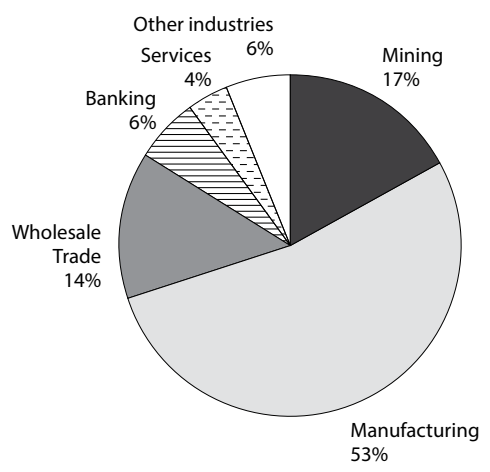

2015

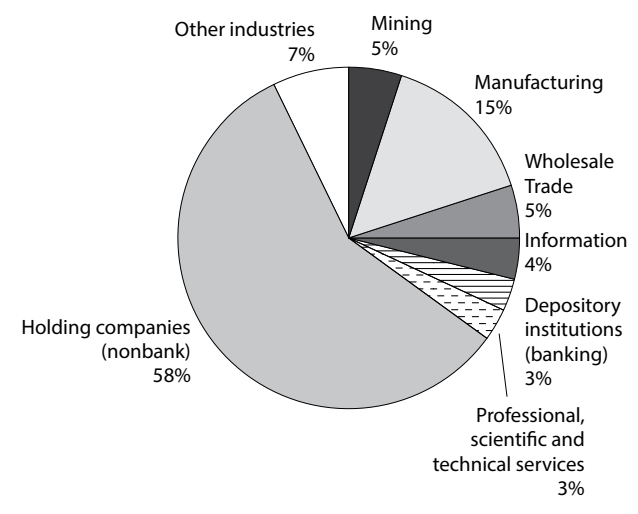

Figure 3. The structure of the United States Foreign Direct Investment abroad in selected years.

Source: based on Bureau of Economic Analysis Statistics (n.d.). 


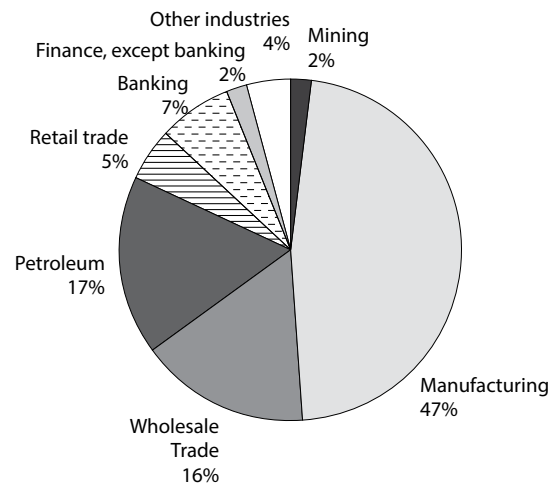

2005

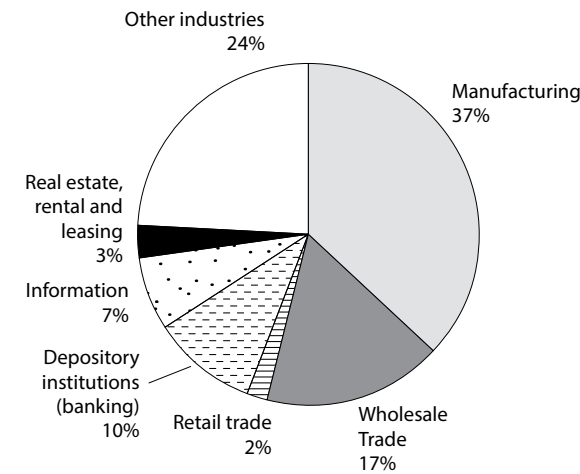

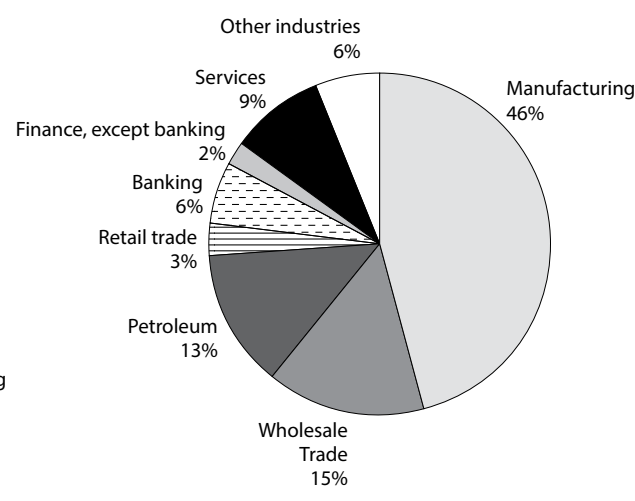

2015

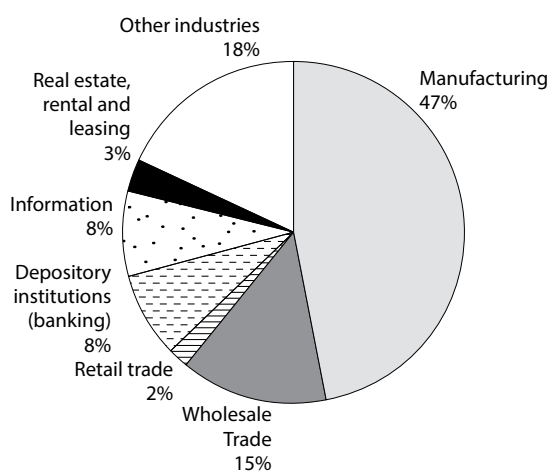

Figure 4. The structure of the Foreign Direct Investment inflow to the United States in selected years.

Source: based on Bureau of Economic Analysis Statistics (n.d.).

Equally important as the analysis of the size of the FDI flows is the analysis of the major investment partners of the country (Tables 1 and 2). During the period of 1980-2015 among the main destinations for the United States FDI outflow were mainly the other developed countries. China, which is very often pointed out by the critics as the main destination of the FDI outflow was in 2015 in the $14^{\text {th }}$ place. It must be highlighted that up to the 1990, the significance of the country was minimal, compared to other countries. The same situation was in the side of FDI inflow. Among the main sources of FDI were mainly other developed countries. The only developing country which reached the list of the top fifteen in the analyzed period was the Republic of Korea. The main partners for the United States in 2015 are Western European countries, Canada and Japan, similarly, like three decades ago. 
Table 1 The major destinations of the United States Foreign Direct Investment outflow (millions of US dollars)

\begin{tabular}{|l|l|r|r|r|r|r|}
\hline \multirow{2}{*}{ No. } & Country & \multicolumn{6}{|c|}{ Year } \\
\cline { 2 - 7 } & & $\mathbf{1 9 8 0}$ & $\mathbf{1 9 9 0}$ & \multicolumn{1}{c|}{$\mathbf{2 0 0 0}$} & \multicolumn{1}{c|}{$\mathbf{2 0 1 0}$} & \multicolumn{1}{c|}{$\mathbf{2 0 1 5}$} \\
\hline 1. & Netherlands & 6.760 & 19.120 & 115.429 & 514.689 & 858.102 \\
\hline 2. & United Kingdom & 27.537 & 72.707 & 230.762 & 501.247 & 593.028 \\
\hline 3. & Luxembourg & 1.098 & 1.697 & 27.849 & 272.206 & 502.998 \\
\hline 4. & Canada & 43.511 & 69.508 & 132.472 & 295.206 & 352.928 \\
\hline 5. & Ireland & 2.031 & 5.894 & 35.903 & 158.851 & 343.382 \\
\hline 6. & Bermuda & 11.519 & 20.169 & 60.114 & 265.524 & 269.329 \\
\hline 7. & Singapore & 1.720 & 3.975 & 24.133 & 102.778 & 228.666 \\
\hline 8. & Australia & 9.089 & 15.110 & 34.838 & 125.421 & 167.401 \\
\hline 9. & Switzerland & 12.863 & 25.099 & 55.377 & 119.891 & 155.221 \\
\hline 10. & Japan & 6.407 & 22.599 & 57.091 & 113.523 & 108.535 \\
\hline 11. & Germany & 15.463 & 27.609 & 55.508 & 103.319 & 108.094 \\
\hline 12. & Mexico & 7.019 & 10.313 & 39.352 & 85.751 & 92.812 \\
\hline 13. & France & 7.391 & 19.164 & 42.628 & 78.320 & 78.282 \\
\hline 14. & China & 49 & 354 & 11.140 & 58.996 & 74.560 \\
\hline 15. & Hong Kong & 2.854 & 6.055 & 27.447 & 41.264 & 64.049 \\
\hline
\end{tabular}

Source: Bureau of Economic Analysis Statistics (n.d.).

Table 2 The major destinations of the Foreign Direct Investment inflow to the United States (millions of US dollars)

\begin{tabular}{|c|c|c|c|c|c|c|}
\hline \multirow[t]{2}{*}{ No. } & \multirow[t]{2}{*}{ Country } & \multicolumn{5}{|c|}{ Year } \\
\hline & & 1980 & 1990 & 2000 & 2010 & 2015 \\
\hline 1. & United Kingdom & 14.105 & 98.676 & 277.613 & 400.435 & 483.841 \\
\hline 2. & Japan & n.s. & 83.091 & 159.690 & 255.012 & 411.201 \\
\hline 3. & Luxembourg & 261 & 2.195 & 58.930 & 170.309 & 328.400 \\
\hline 4. & Netherlands & 19.140 & 64.671 & 138.894 & 234.408 & 282.525 \\
\hline 5. & Canada & 12.162 & 29.544 & 114.309 & 192.463 & 268.972 \\
\hline 6. & Switzerland & 5.070 & 17.674 & 64.719 & 180.642 & 257.859 \\
\hline 7. & Germany & 7.596 & 28.232 & 122.412 & 203.077 & 255.471 \\
\hline 8. & France & 3.731 & 18.650 & 125.740 & 189.763 & 233.844 \\
\hline 9. & Belgium & 1.554 & 3.900 & 14.787 & 69.565 & 80.134 \\
\hline 10. & Spain & n.s. & 792 & 5.068 & 43.095 & 61.947 \\
\hline 11. & Sweden & 1.670 & 5.484 & 21.991 & 38.780 & 46.928 \\
\hline 12. & Australia & n.s. & 6.542 & 18.775 & 35.632 & 42.301 \\
\hline 13. & Republic of Korea & n.s. & 1.009 & 3.110 & 15.746 & 40.130 \\
\hline 14. & Italy & 408 & 1.524 & 6.576 & 20.142 & 28.648 \\
\hline 15. & Singapore & n.s. & 1.289 & 5.087 & 21.517 & 19.423 \\
\hline
\end{tabular}

n.s. - not specified

Source: Bureau of Economic Analysis Statistics (n.d.).

Another aspect essential to the analysis of the United States FDI is the structure of investment in the category "manufacturing" (Figures 5, 6,7 and 8). The presented analysis of data on these investments leads to the conclusion that the investments abroad were 
dominated by the production of chemicals, electronics and computers. Investment inflow into the United States also were dominated by chemicals and machinery sectors. All these sectors represent middle- and high-technologically advanced industries.

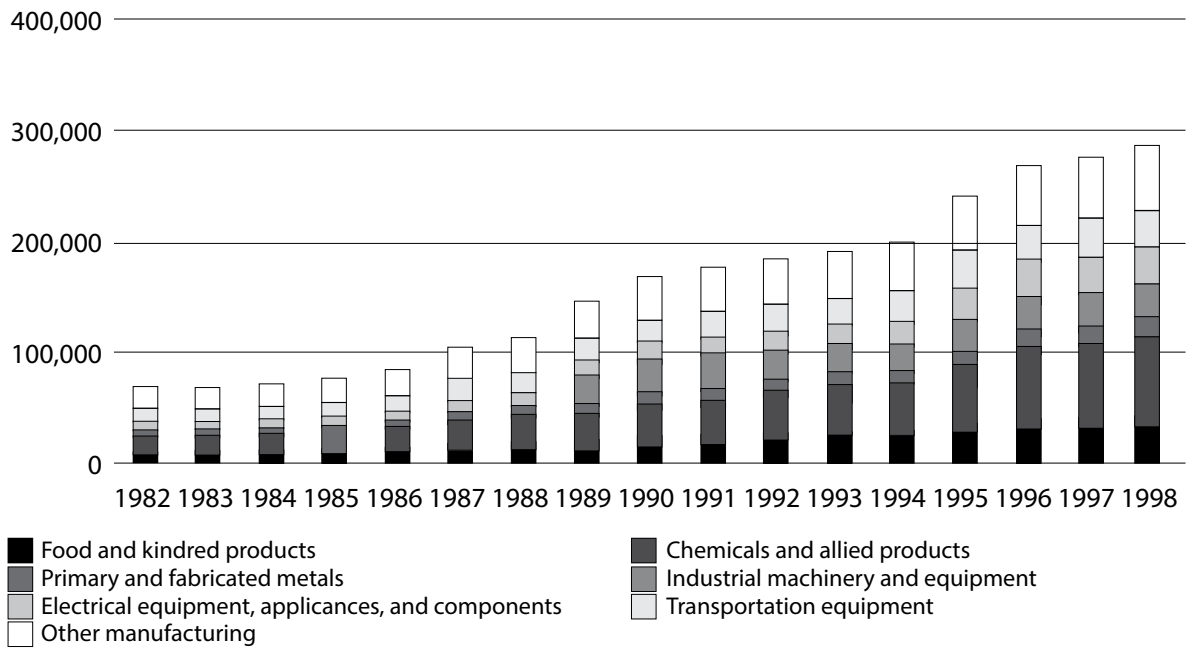

Figure 5. The structure of manufacturing Foreign Direct Investment outflow during the period 1982-1998.

Source: based on Bureau of Economic Analysis Statistics (n.d.).

800,000

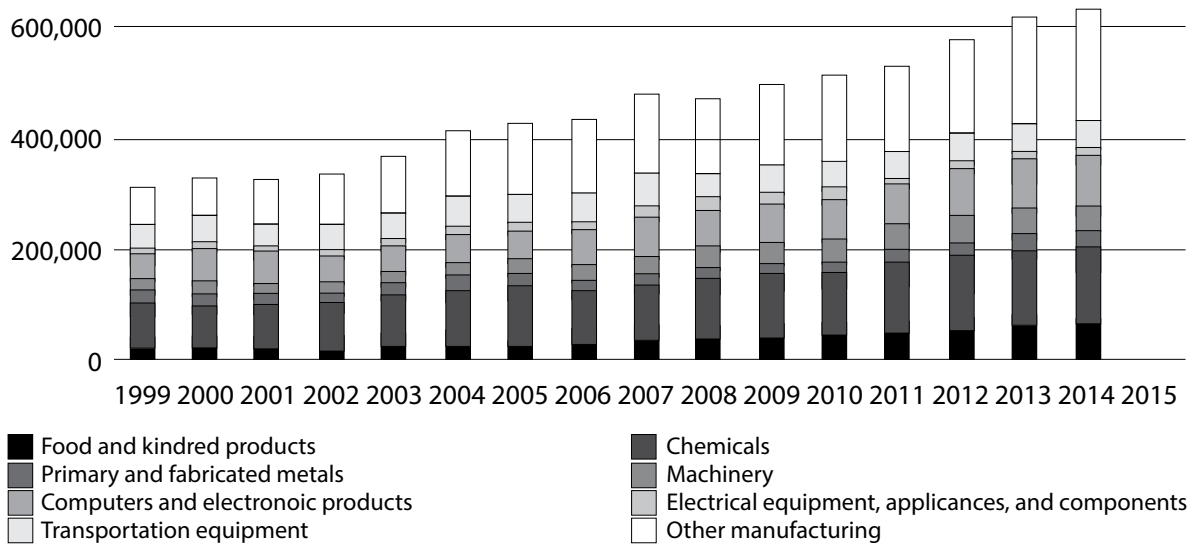

Figure 6. The structure of manufacturing Foreign Direct Investment outflow during the period 1999-2015.

Source: based on Bureau of Economic Analysis Statistics (n.d.). 


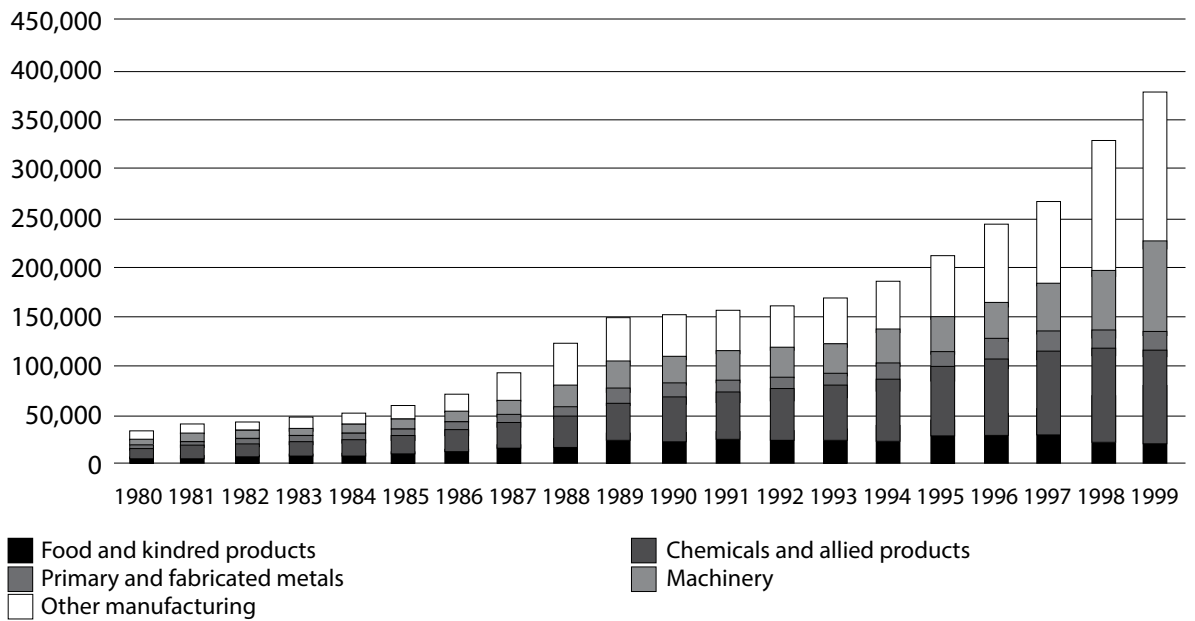

Figure 7. The structure of manufacturing Foreign Direct Investment inflow during the period 1980-1999.

Source: based on Bureau of Economic Analysis Statistics (n.d.).

$1,500,000$

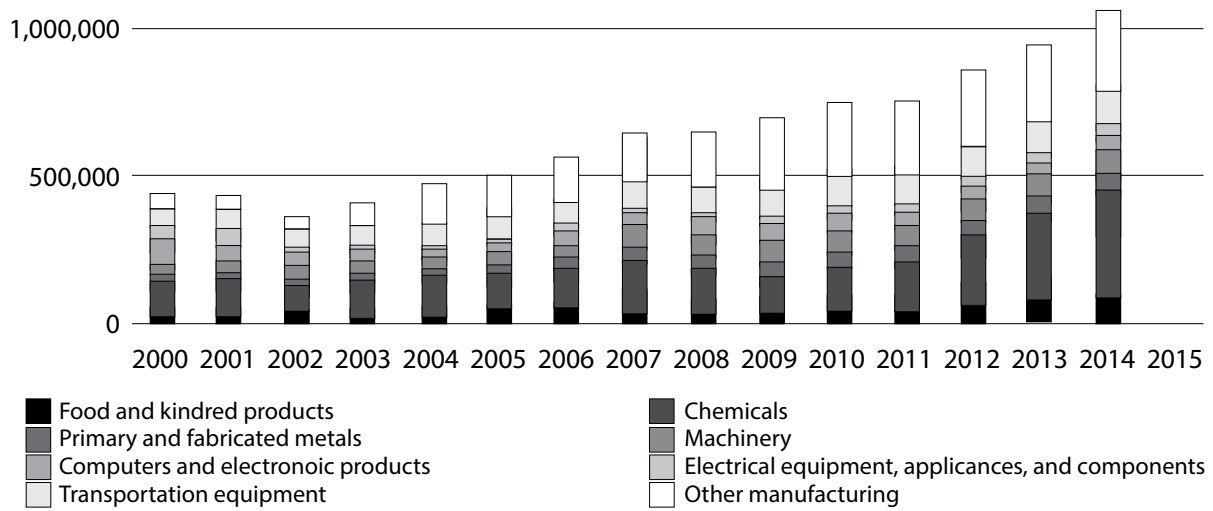

Figure 8. The structure of manufacturing Foreign Direct Investment inflow during the period 2000-2015.

Source: based on Bureau of Economic Analysis Statistics (n.d.). 


\section{Discussion and conclusions}

On the basis of the theoretical background and presented data, it is possible to evaluate the investment flows in and out of the United States and their significance, to enumerate the determinants of these flows, and to identify what changes are necessary in order to improve the mutual investments in the future.

It was already highlighted, that historically the United States was, on one hand the biggest world investor, but on the other hand a desirable market for foreign investors. Since the Second World War, it has been the largest economy in the world and most important market. Moreover, this market provided protection for investors and has a great potential for development. While the United States market was attractive for investors, the domestic corporations were seeking for markets in other countries. Originally, the best prospects offered Western European countries. They provided geographical contiguity, similar political and economic systems, and were relatively close in cultural terms. Together with sound infrastructure and technically skilled labor, the Western Europe was an attractive market for FDI from the United States. At that time the main motive for investors was the "location."

With time markets changed, the competition increased and in Europe occurred slowdown. All the processes caused that the multinationals from the United States started to searching for another destination for their FDI. The main motive for investments become "efficiency-seeking" and "market-seeking." They found that a very favorable location for investments are Eastern Asian countries (South Korea, Thailand, Malaysia, Philippines, Singapore, etc.) because of their impressive economic growth of these countries. The process of transferring FDI to those markets during the 1980s and the 1990s was favorable for multinationals from the United States and they benefited from the change during the two decades. Unfortunately, under the dynamic economic development the emerging markets of East Asia also changed. They upgraded the technology, local wages started to increase, and began to appear other weaknesses of these markets (e.g. signs of over-investment). The rapid inflow of investments was hampered by the currency crisis of the mid-1990s. The United States multinationals started to search for new locations for their investments (Sethi, Guisinger, Phelan, \& Berg, 2003). They also changed the purpose of their investments and instead of manufacturing activity their principal aim became the financial activities. The investments started to outflow from the 'Asian tigers' and to inflow in those markets which offered the highest rate of return for capital. Among them were Western European countries, the United States and some others dependent territories.

The changing trends of FDI flows were determined mainly by the globalization process, macro-economic policies and multinational companies' strategies. Since the 1990s entities from emerging markets began their process of internationalization, which triggered the FDI inflow to the United States. The main motive for those companies became "strategic asset-seeking" what means that crucial deter- 
minant was not the efficiency of the investor, but rather the advanced technology which the investors were eager to acquire. Firms increasingly used FDI to obtain strategic asset (tangible and intangible) that were not available at home. In this way firms from emerging markets used FDI to build advantages that ought to support their long-term expansion. This process nowadays relates to Chinese companies, which in the past were concentrated on securing natural resources and building the infrastructure necessary for boosting cross-border trade. Actually, these firms are becoming more and more important source of FDI and are trying to upgrade their technology, develop their value chains and improve their managerial skills to become globally competitive. In countries like the United States they are able to find the proper environment and skilled workforce, which are very propitious for their development (Rosen \& Hanemann, 2012).

The observed processes exerted an impact on the reaction of the White House administration and other entitled institutions. In consequence during the last decade the United States have begun to apply some restrictions for the FDI from emerging markets, especially from China. The United States Congress is in favor to bar the foreign companies from acquiring domestic companies in the country. Behind the approach is fear that Chinese enterprises could use acquired technologies to benefit Chinese national interests at the expense of the United States market (Dyer, 2016). The controversial point is that sometimes the investors are Chinese state-owned enterprises. During the last few years, a number of high-profile Chinese investments have been blocked by CIFUS and the United States President because of this factor (e.g. Sany Group's acquisition of four small wind farms, Huawei's acquisition of 3 Leaf, Fujian Grand Chip Investment Fund acquisition of Aixtron) (Gong \& Forsythe, 2013; Mauldin, 2016).

It must be highlighted that despite the restrictions there is potential for FDI flow growth between the United States and some emerging markets, especially China. Particularly, it refers to some branches of industry, e.g. minerals and food. Sometimes the entrance of foreign investors into the United States can be very beneficial for local companies which want to discard some unnecessary assets when moving up the value chain. Additionally, the growing FDI from emerging markets in developed countries can accelerate the process of opening the emerging markets for foreign capital. There is a great field for cooperation beneficial to both sides provided that emerging markets (especially China) liberalize their restrictions in some modern services like finance, telecom, health, education, media, etc. Moreover, China should strengthen its law in order to protect intellectual property rights to a greater extent. If the country will do it, the cross-investment between China and the United States can play a more important role in the future and be beneficial to both of the economies.

The literature review and the analysis lead to the conclusion that the described FDI flows which occurred during the period of 1980-2015 was not a negative process for the United States economy. The process was potentially favorable for multi- 
national companies from the country. They exploited the opportunities to increase their production efficiency, found new markets and improved their competitive position on international markets. Moreover, these FDI inflows and outflows to the United States were relatively balanced during the whole analyzed period. There was a small surplus of the FDI outward stock, what was beneficial for the local enterprises' competitiveness. None of the White House administrations' during the analyzed period triggered a particularly significant change in the process.

The change in the structure of the FDI outflow (decrease of the FDI share in the "manufacturing" sector and the growth of the share in the "holding companies") was also beneficial to the United States. Maintaining large investments abroad enabled for the country to keep its competitive position in the face of the dynamic development of other markets. The somewhat different situation is associated with the FDI inflow. It can be stated that the share of investments in "manufacturing" and "trade" sectors is too large and that is why some kind of government policy related to the FDI inflow is needed. It should not, however, be a policy limiting investment inflow to the United States, but more desirable is a policy which determines the acceptance of FDI inflow from emerging markets in return for greater openness of these markets in response.

In conclusion, on the basis of the analysis, it can be stated that the FDI flows have not caused a big threat to the United States economy. Like any process, they generate some concerns, but also many benefits. In some exceptional situations state interventions are justified, but essentially the United States market should remain open to the FDI flows. If there is applied any policy towards this kind of capital flows it should be a policy supporting the investments instead of constraining them.

\section{References}

Alvarez, J.E., Sauvant, K.P., Ahmed, K.G., \& Vizcaíno, G.P. (2011). The Evolving International Investment Regime: Expectations, Realities, Options. Oxford: Oxford University Press.

Bureau of Economic Analysis Statistics (n.d.). Retrived from: www.bea.gov/international [accessed: 14.01.2016].

Campbell, D.C., \& McElrath, R.G. (1990). The Employment Effects of Multinational Enterprises in the United States and of American Multinationals Abroad (vol. 64). Geneva: International Labour Organization.

Desai, M.A., Foley, C.F., \& Hines, J.R. (2009). Domestic effects of the foreign activities of US multinationals. American Economic Journal: Economic Policy, 1(1), 181-203.

Dunning, J.H. (1980). Toward an eclectic theory of international production: Some empirical tests. Journal of International Business Studies, 11(1), 9-31.

Dyer, G. (2016). US urged to ban acquisitions by Chinese state-owned companies. Financial Time, (November 16).

Exon-Florio Amendment (1988). In Omnibus Trade and Competitiveness Act of 1988, \$5021, Public Law 100-418, August 23. 
Foreign Investment and National Security Act of 2007, Public Law 110-49, July 26, 2007.

Gong, L., \& Forsythe, A. (2013). CFIUS and Chinese investment: Lessons from the Smithfield Deal. Corporate Practice Newswire.

Jackson, J.K. (2013). U.S. Direct Investment Abroad: Trends and Current Issues. Washington, DC: Congressional Research Service.

Mauldin, W. (2016). Obama blocks Chinese bid for technology Aixtron. Wall Street Journal (December 3).

Rosen, P.D., \& Hanemann, T. (2012). The rise in Chinese overseas investment and what it means for American businesses - China's growing presence abroad brings new competition but also commercial opportunities. China Business Review, 39(3), 18.

Sethi, D., Guisinger, S.E., Phelan, S.E., \& Berg, D.M. (2003). Trends in foreign direct investment flows: A theoretical and empirical analysis. Journal of International Business Studies, 34(4), 315-326.

Statement on International Investment Policy (1983). In Public papers of the Presidents of the United States. Washington: The U.S. Government Printing Office.

Tang, J., \& Altshuler, R. (2015), The Spillover Effects of Outward Foreign Direct Investment on Home Countries: Evidence from the United States, retrieved from: https://ssrn.com/abstract $=2545129$ [accessed: 14.01 .2017 ].

UNCTAD Statistics (n.d.). Retrived from: http://unctadstat.unctad.org/wds/TableViewer/tableView.aspx?ReportId=96740 [accessed: 19.12 .2016 ].

\section{Note about the Author}

Piotr Łasak, Ph.D. - Assistant Professor of the Institute of Economics, Finance and Management, the Jagiellonian University. His research interests focus on topics related to international financial markets development and regulation. 